\title{
Effects of storage conditions on the fatty acid composition of the butter of tallow tree (Pentadesma butyracea)
}

\author{
Bernolde P. Ayegnon ${ }^{1}$, Adéchola P.P. Kayodé ${ }^{1,2^{\star}}$, Islamiath Nassia ${ }^{1}$, Bruno Barea ${ }^{3}$, Fidèle P. \\ Tchobo 4 \& Joseph D. Hounhouigan² \\ ${ }^{1}$ Laboratoire de Valorisation et de Gestion de la Qualité des Bio ingrédients Alimentaires (LABIO) ; Faculté des \\ Sciences Agronomiques ; qUniversité d'Abomey-Calavi; 03 BP 2819 Jericho Cotonou, Bénin. \\ ${ }^{2}$ Laboratoire de Biochimie Microbienne et de Biotechnologie Alimentaires (LMBA), Faculté des Sciences \\ Agronomiques, ףUniversité d'Abomey-Calavi; 03 BP 2819 Jericho ; Cotonou, Bénin \\ 3Unité mixte de recherche ingénierie des agropolymères et technologies émergentes (IATE) CIRAD, INRA, UM II, \\ Montpellier Supagro, Place Pierre Viala, Bat 3134060 Montpellier Cedex 1, France \\ ${ }^{4}$ Laboratoire d'Étude et de Recherche en Chimie Appliquée (LERCA), Unité de Recherche en Génie Enzymatique et \\ alimentaire ; École Polytechnique d'Abomey-Calavi, Université d'Abomey-Calavi; T01 BP 2009 Cotonou, Bénin. \\ * Correspondences should be addressed: Tel: (+229) 97870734; E-mail:polykap@yahoo.fr
}

Original submitted in on $6^{\text {th }}$ July 2015. Published online at www.m.elewa.org on $31^{\text {st }}$ August 2015

http://dx.doi.org/10.4314/jab.v92i1.7

\begin{abstract}
Objective: In this study, the effect of various storage conditions of the kernel of $P$. butyracea on the fatty acid profile of the derived butter was evaluated.

Methodology and results: An experimental design was set up to assess the effects of kernel boiling, the packaging material and the storage duration on the kernel butter yield and water activity; and on the fatty acid composition of derived butter. The fatty acid composition of the butter varied significantly according to the storage conditions of the kernels. The palmitic, stearic and linoleic acids content of the butter tend to increase because of the storage duration while the oleic acid decreases during storage.

Conclusions and Application of results The kernels dried without boiling, stored in jute bag for a duration of less than 6 months provided a butter with optimum yield and less modifications in its fatty acid composition. Pentadesma butyracea butter from kernels stored in jute bags maintains its physicochemical quality, thus these packaging materials should be recommended.
\end{abstract}

Key words: Pentadesma butyracea, oil seed, storage, butter, fatty acid

\section{INTRODUCTION}

Forest products contribute significantly to the food security of millions of people in Africa. Their use also contributes to biological diversity of forest resources (Vantomme, 1999). Pentadesma butyracea Sabine (Clusiaceae) (Photo 1) is a ligneous forest species of multipurpose uses. It is widely distributed in Africa from Guinea-Bissau to the West of the Democratic Republic of Congo. The plant is known as "tallow tree" or "butter tree" in English, "arbre à suif" or "arbre à beurre" in French, "Krinda" in Côte d'Ivoire, "Abotoasebie" in Ghana, "Agnuhé" in Gabon and "Kpangnan" or 
"Sesseido" in Benin. Pentadesma butyracea is found in the centre and northern part of Benin in forest galleries and along waterways (AvocèvouAyisso 2011; Natta et al., 2010). The fresh kernels consumed like kola (Sinsin \& Sinadouwirou 2003) are rich in edible butter similar to Shea butter (Tchobo et al., 2007). The Pentadesma butyracea butter is used in traditional medicine as massage oil, in skin and hair care and in the manufacturing of soap because of its softening, lubricating and healing qualities (Dencausse et al., 1995). In Central Africa, notably in Gabon, the sweet mesocarp of mature fruits is used to make fruit juice (White \& Albernethy, 1996). In spite of its potential application in food and cosmetic industries, very little is known on the quality attributes of the Pentadesma butyracea butter. Previous studies showed that the compositions in fatty acids and in triglycerides of Pentadesma butyracea butter are similar to that of Shea butter ((Dencausse et al. 1995). Tchobo et al. (2013) evaluated the physicochemical characteristics of the butter of Pentadesma butyracea and reported that oil content is $41.90 \%$, crude proteins content is $44.0 \%$, lysine content is $3.2 \% \mathrm{DM}$; methionine content is $1.6 \%$ and cysteine is $1.5 \%$. Evrard et al. (2005) reported that the oil cakes of Pentadesma butyracea kernels are very poor in proteins; particularly in essential amino acids. The colour characteristics of the butter of Pentadesma butyracea kernel are reported to be $L^{*}=53.07$; $a^{*}=$ 11.77; and $b^{*}=7.76$ (Aïssi et al., 2011). Moreover, the technical itinerary of the traditional processing of the kernels from Vitellaria paradoxa and Pentadesma butyracea is nearly the same (Aïssi et al., 2011). Lipid oxidation is one of the major causes of quality deterioration in many oil rich food systems. Pentadesma butyracea nut contain approximatively $48.66 \%$ of oil (Aïssi et al., 2012). $52.81 \%$ of the Pentadesma butyracea nut oil is composed of unsaturated fatty acids of which $49.86 \%$ of saturated fatty acids. This fatty acid profile makes the Pentadesma butyracea butter and derived products susceptible to deterioration due to rancid development and off-flavours through lipid oxidation. Oxidation of lipids may occur during long term exposure to oxidative agents during process like storage. In the present study, kernels of Pentadesma were subjected to various treatments including boiling, drying, packaging prior to storage. The change in the fatty acid composition of the derived butter was monitored every three month of the storage of 9 months.

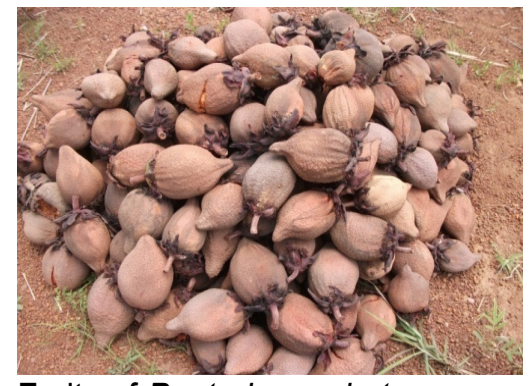

Fruits of Pentadesma butyracea

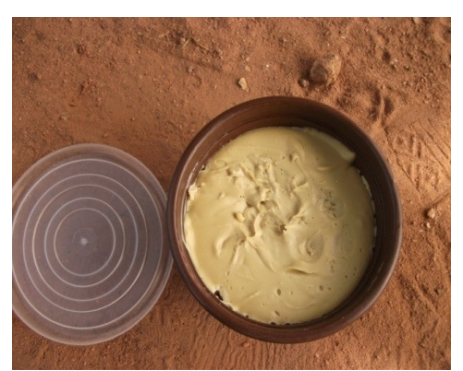

Butter of Pentadesma butyracea
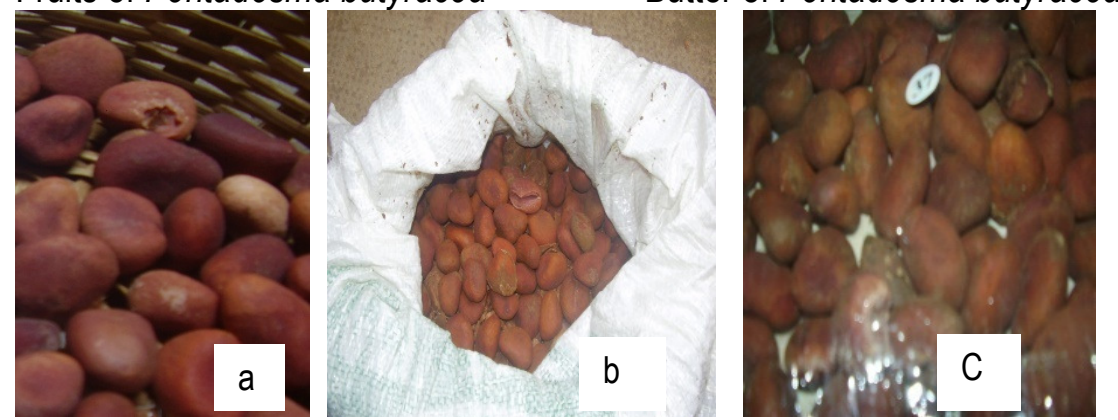
Photo1: Kernels boiled and dried stored in basket (a), Kernels boiled and dried stored in jute bag (b), kernels dried without boiling stored in basket $(\mathrm{C})$, kernels dried without boiling stored in jute bag

\section{MATERIAL AND METHODS}

Plant material: Fresh fruits of Pentadesma butyracea were collected from May to June 2013 in the forest galleries of Péperkou village in the community of Toucountouna $\left(10^{\circ} 20^{\prime}-10^{\circ} 45^{\prime} \mathrm{N}\right.$ and $\left.1^{\circ} 10^{\prime}-1^{\circ} 40^{\prime} \mathrm{E}\right)$ located in the Northwest of Benin. Forty kilograms of $P$ butyracea fruits were randomly collected from different trees. The fruits were transported to the laboratory where the kernels were extracted, cleaned and subjected to various treatments prior to storage.

Experimental design: An experimental design with 3 factors including storage duration, the pre-treatment and the packaging materials was used to study the effects of storage conditions on the fatty acid profile, the oil yield, the ash content and the water activity of the kernel of the $P$. butyracea and derived butter. The storage duration varied from 0 to 12 months and the kernel pre-treatments includes the fresh kernel without any treatment, the boiled and dried kernel and the dried kernel. The packaging materials included the jute bag and the basket container. Boiling was performed at a temperature of $90-100^{\circ} \mathrm{C}$ during $60 \mathrm{~min}$ and kernel drying was done at a temperature of $45^{\circ} \mathrm{C}$ during 72 hours. Samples were stored at ambient temperature (temperature: $29.5^{\circ} \mathrm{C}$; relative humidity $65 \pm 3 \%$ ) (Figure 1).

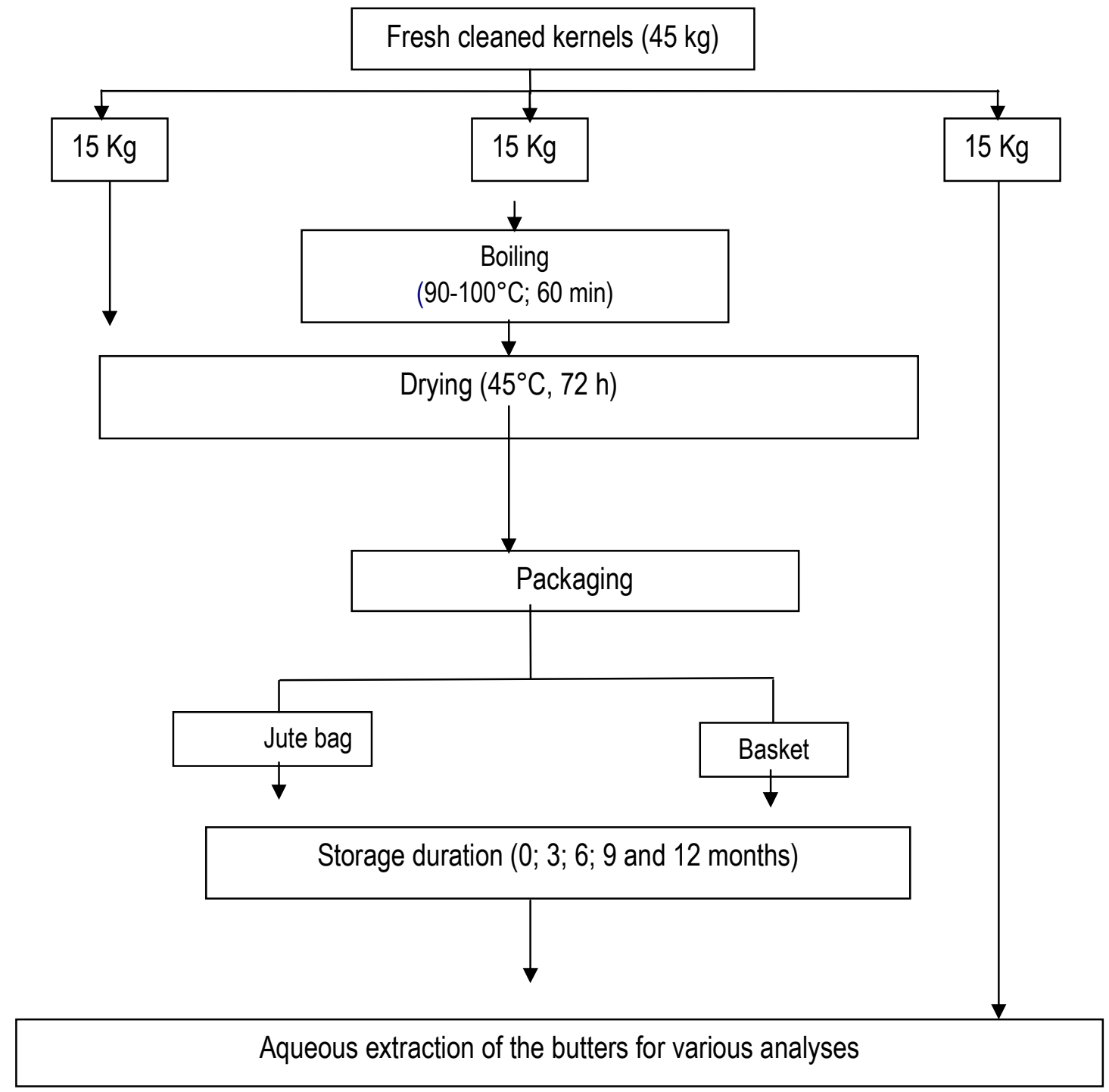


Figure 1: Experimental design

Determination of water activity, oil yield and ash content of the kernels: Samples of $P$. butyracea kernels were drawn at different storage duration and analyzed for their Water activity $\left(a_{w}\right)$, ash and oil contents. The Water activity (Aw) was measured according to the method described by Anihouvi et al. (2006), using a thermo-hygrometer recorder (Rotronic HygroLab 2, 8303 Bassersdorf). About $2 \mathrm{~g}$ of sample were put into the instrument and the $a_{w}$ was measured automatically after starting the program. The ash content was determined following the AOAC standard methods (AOAC, 2002). Values were calculated in percentage of dry matter. The yield of Pentadesma butyracea butter was expressed on wet weight as the percentage of mass of clear oil after filtering on the mass of the kernels used.

Butter yield $(\%)=\frac{\text { Weight of butter obtained }}{\text { Weight of kernel processed }} \times 100$

Oil extraction : Butter was extracted from the kernels using the traditional procedure (Ayegnon et al. 2015).The kernels were sorted, crushed and approximately 300 grams $(\mathrm{g})$ of crushed kernels were roasted for $120^{\circ} \mathrm{C}$ during 30 minutes. The roasted kernels were ground into fine powder. Tepid water was added to the fine powder, which was churned for 2 hours using a mixer to generate a cream. The cream is recovered and washed with water. The derived raw butter was heated at a temperature of $120-130^{\circ} \mathrm{C}$ to obtain an oil, which is filtered and cooled to give the

\section{RESULTS AND DISCUSSION}

Effects of the storage conditions on the kernel oil yield and water activity: The result of ANOVA showing the effect of factors i.e. kernel pre-treatments, packaging material and the storage duration on the kernel water activity, the oil yield and the fatty acid profile of the derived butter is presented in Table 1. There is a significant effect of the 3 factors studied on the oil yield of the kernel. The interactions of the factors are not significant on the kernel water activity while they significantly affect the kernel oil yield. Particularly the interactions between the pre-treatments and the packaging material (Pre-treatment *Packaging) and between the storage duration and the packaging material (Storage duration*Packaging) were significant butter. The butter obtained was preserved in the refrigerator at $4-7^{\circ} \mathrm{C}$ for various laboratory analyses.

Fatty acid analysis: The fatty acid composition of $P$. butyracea butters was analyzed with a gas chromatography following the method described by Tchobo et al. (2007). In a 25-ml round bottom flask, oil samples $(10 \mathrm{mg})$ were added to sodium methylate solution $(3 \mathrm{~mL})$ containing phenolphthalein. The mixture was refluxed for $10 \mathrm{~min}$ and $3 \mathrm{~mL}$ methanolic $\mathrm{HCl}$ were added until phenolphthalein discoloration occurred. The mixture was refluxed again for $10 \mathrm{~min}$ and cooled to room temperature. Hexane $(8 \mathrm{~mL})$ and water $(10 \mathrm{~mL})$ were added and the organicphase recovered, dried over anhydrous sodium sulfate and filtered for subsequent GC analysis. An Agilent 6890series GC apparatus provided with a Supelcowax 10capillary column (SGE, Courtaboeuf, France) with the following characteristics: length, $30 \mathrm{~m}$; internal diameter, 0.32 $\mathrm{mm}$, film thickness $0.25 \mu \mathrm{m}$, was used. Fatty acid methyl esters were directly injected into the GC. The carrier gas was helium with a flow rate of $1 \mathrm{~mL} / \mathrm{min}$, and a splitting ratio of $1 / 80$. The injector temperature was $250{ }^{\circ} \mathrm{C}$ and that of the FID was $270{ }^{\circ} \mathrm{C}$. The temperature settings were as follows: $150-225^{\circ} \mathrm{C}$ at 5 ${ }^{\circ} \mathrm{C} / \mathrm{min}$, and then held at $225^{\circ} \mathrm{C}$ for 2 min. Fatty acids were identified by comparison with commercially available fatty acids standards.

Statistical analysis: Statistical analysis were performed using the statistical program SPSS16.00 (SPSS, Chicago, IL, USA) and the one-way ANOVA model was used applying the Tukey's post-hoc test to evaluate significant difference among means at $p<$ 0.05 .

with respect to oil yield $(p \leq 0.05)$. Figure 2 showed the trend in the kernel oil yield as function of the storage duration with respect to various pre-treatment and packaging materials. Under the investigated storage conditions, the kernel oil yield varied from $9.73 \%$ to $31.2 \%$. The highest oil yield was obtained from the kernels directly dried and stored in jute bags after 12 months of storage. The lower value of oil yield was obtained in the fresh kernels without any treatment. For all samples, the oil yield tended to increase because of the storage duration. Oil yield from kernels directly dried was significant higher $(P \leq 0.05)$ than the oil yield from the kernels boiled and dried. Likewise, kernels pre-treated (boiled and/or dried) yield more oil than $(P$ 


\section{Ayegnon et al. J. Appl. Biosci. Effects of storage conditions on the fatty acid composition of the butter of tallow tree (Pentadesma butyracea)}

$\leq 0.001$ ) untreated kernel (fresh). It is most likely that

bursting of the oleiferous cells and subsequently pre-treatments such as boiling/drying facilitate the allowed the oil release.

Table 1: Analyze of variance showing the effect of the kernel pre-treatments, the packaging material and the storage duration on kernel water activity and oil yield and on the fatty acid composition of the derived butter

\begin{tabular}{|c|c|c|c|c|c|c|c|}
\hline \multirow[b]{2}{*}{ Factors } & \multirow[b]{2}{*}{ DL } & \multicolumn{6}{|c|}{ Fischer value (F) } \\
\hline & & $\begin{array}{c}\text { Oil } \\
\text { yield }\end{array}$ & $\begin{array}{l}\text { Water } \\
\text { activity }\end{array}$ & $\begin{array}{l}\text { Palmitic } \\
\text { acid }\end{array}$ & $\begin{array}{l}\text { Stearic } \\
\text { acid }\end{array}$ & $\begin{array}{l}\text { Oleic } \\
\text { acid }\end{array}$ & $\begin{array}{l}\text { Linoleic } \\
\text { acid }\end{array}$ \\
\hline Pre-treatment & 2 & $\begin{array}{c}306.00 \\
5^{* *}\end{array}$ & $\begin{array}{c}854.771^{*} \\
*\end{array}$ & $10.771^{*}$ & $102.478^{\star *}$ & $101.098^{* *}$ & 0.104 \\
\hline Storage duration & 3 & $\begin{array}{c}211.39 \\
6^{* *}\end{array}$ & $\begin{array}{c}210.115^{*} \\
*\end{array}$ & $24.375^{* *}$ & $457.849^{* *}$ & $29.196^{* *}$ & 0.104 \\
\hline Packaging material & 1 & $\underset{*}{96.848^{*}}$ & $12.217^{*}$ & $25.208^{\star *}$ & 0.618 & $232.232^{\star *}$ & 0.000 \\
\hline Storage duration*Packaging & 3 & $\underset{*}{10.671^{*}}$ & 1.201 & $6.458^{*}$ & $214.727^{\star *}$ & $13.125^{\star *}$ & 0.313 \\
\hline Packaging*Pre-treatment & 1 & $4.554^{*}$ & 0.445 & 1.875 & $53.175^{\star \star}$ & $122.232^{\star *}$ & 0.000 \\
\hline $\begin{array}{l}\text { Duration*Packaging*Pre- } \\
\text { treatment }\end{array}$ & 3 & 2.17 & 0.27 & 1.875 & $6.967^{*}$ & $12.411^{*}$ & 0.313 \\
\hline
\end{tabular}

*:Significant with the threshold of $2 \%,{ }^{* *}$ :Significant with the threshold of $1 \%$.

This study data are similar to findings by Aïssi et al. (2011) who reported an oil yield of $25 \%$ for roasted kernels and $33.5 \%$ for the kernels boiled and dried. With respect to the packaging materials, kernels stored in jute bag yield more oil than those stored in basket ( $P$ $\leq 0.05$ ). All the studied factors affected the water activity $\left(a_{w}\right)$ of the kernels, but their interactive effects are not significant on these parameters (Table1). Before storage, the $a_{w}$ of the fresh kernels was 0.93 . In the kernels boiled and dried it varied from 0.57 to 0.69 (Figure 3). The highest value was observed in the kernels stored in basket bag for 3 months; while the lowest value was obtained in the kernels stored in jute bag after 12 months of storage. Compared to butter made from cow's milk and margarine, the $a_{w}$ of $P$. butyracea butter is much lower. Unsalted butter and margarine have an $a_{w}$ of about 0.99 while salted butter or margarine has an $a_{w}$ of about 0.91 (Welti-Chanes et al., 2007). In this respect $P$., butyracea butter is similar to cocoa butter. Overall, kernels stored in jute bag exhibited low level of $a_{w}$ compared to those in basket while the boiled and dried kernels seem to possess relatively high $a_{w}$ in comparison to the dried kernel. An implication of this result is that kernels with high level of water activity are more subject to deteriorations such as microbial, enzymatic and oxidative degradations. Thus, modifications in the fatty acid profile of the kernel butter could be expected. 


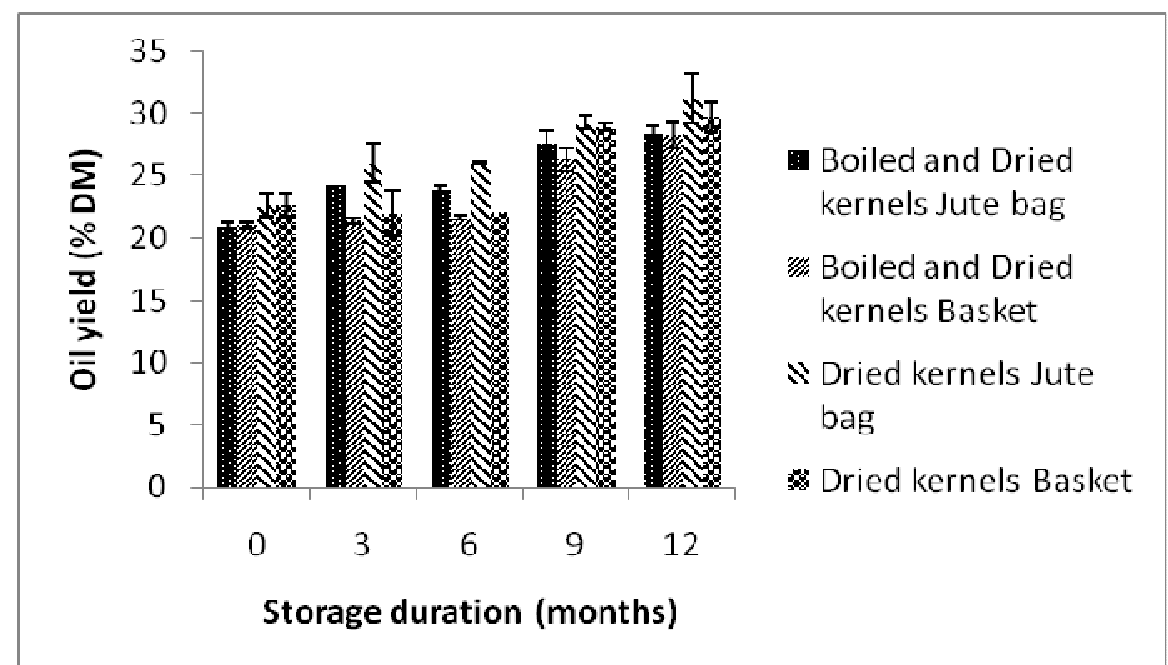

Figure 2: Effect of storage duration, pre-treatment and packaging materials on oil yield of the kernels

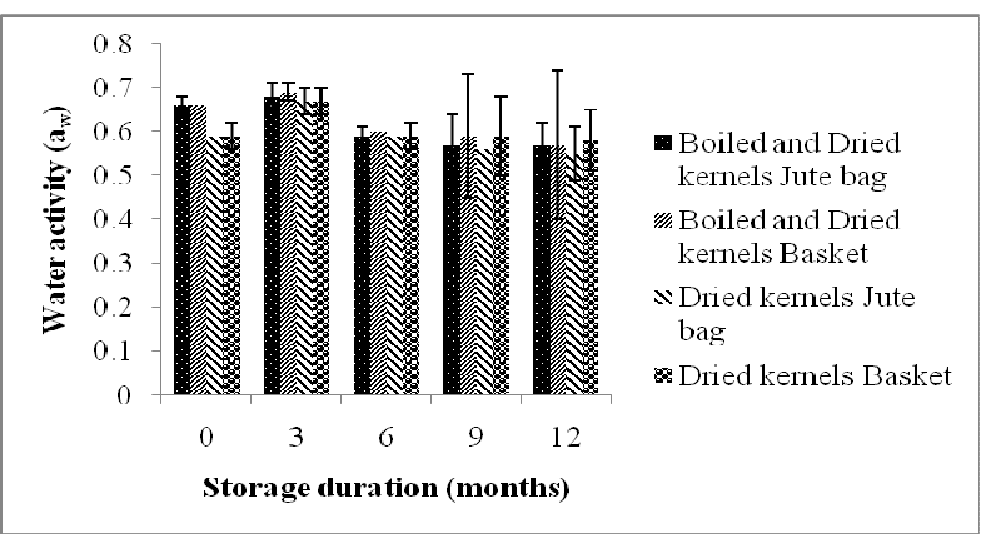

Figure 3: Effect of storage duration, pre-treatment and packaging materials on water activity of the kernels

Effects of the storage conditions on the fatty acid profile of the butter extracted from Pentadesma kernels : The analysis of variance revealed significant $(P \leq 0.05)$ effects of kernel boiling, packaging materials and storage duration on the palmitic acid (C16:0), stearic acid (C18:0) and oleic acid (C18:1) contents of the derived butter while the level of linoleic acid (C18:2) was not significantly affected. More specifically, the linear and the interactive effects of these factors were significant with respect to the three fatty acids mentioned above (Table 1). Figure 4 showed the trend in the palmitic acid content of the butter as function of the storage duration with respect to various pre-treatment and packaging materials. Under the investigated storage conditions, the palmitic acid content of the butter varied from 2.2 to $2.6 \%$. The highest value was obtained from the kernels dried without boiling and the lower value was obtained in the boiled and dried kernels. The palmitic acid content of the butter tends to increase during the first six month of storage of the kernels irrespective to the other storage conditions. Higher amounts of palmitic acid were found in the kernels stored for duration longer than 6 months. With respect to the packaging materials, kernels stored in baskets yield butter with higher amount of palmitic acid compared to those stored in jute bags $(P<0.05)$. As far as the pre-treatment is concerned, no significant difference $(P<0.05)$ was detected in the palmitic acid content of butters from fresh kernels, boiled and dried kernels and directly dried kernels. The effect of the storage duration on the stearic acid content of the butter was significant only after 3 months of storage (Figure 5). The highest amounts of stearic acid were found in butters extracted from kernels of 9 months of storage. With respect to packaging materials, the highest concentration of stearic acid was recorded in butter from kernels stored in baskets. There is a significant difference $(P \leq 0.001)$ in the stearic acid 
content of butters from fresh kernels, from boiled and dried kernels and butter from directly dried kernels. The highest value of stearic acid was obtained from butters extracted from directly dried kernels and the low level in boiled and dried kernels stored in jute bag. The low level of stearic acid recorded in the butters from boiled kernels could be explained by leaching of the fatty acids (dissolution of fatty acids) in the cooking medium. This phenomenon of dissolution was also observed by Aïssi et al. (2011) in a study on butter extraction from Pentadesma kernels. Overall, the oleic acid concentration in all samples is significantly affected by the storage duration (Figure 6). Longer storage duration of kernels results in the reduction of the oleic acid concentration in the derived butters. A decrease in oleic acid content could be expected in accelerated oxidation conditions with storage duration (Beltrán et al., 2009). Nuernberg et al. (2006) reported that storage of plant oils for $144 \mathrm{~h}$ caused significant decrease in the concentration of linoleic acid (18:2n-6), arachidonic acid $(20: 4 n-6)$ and docosapentaenoic acid (22:5n-3). Nkouam et al. (2007) also observed an increase of the proportion of the palmitic acid and the decrease of the proportion of the linoleic acid throughout storage of aiélé seeds (Canarium schweinfurthii Engl.) to $18^{\circ} \mathrm{C}$. About the packaging materials, the lowest level of oleic acid was obtained in butter from kernels stored in jute bags. Higher amounts of oleic acid $(P \leq 0,001)$ were found in butters from boiled and dried kernels, while butters from kernels directly dried exhibited lower amounts of oleic acid. There is no significant effect of the storage conditions on the linoleic acid concentration of the butters extracted from the difference kernels $(p>$ $0.05)$. Thus, the linoleic acid appears to be stable during the storage of the kernels of Pentadesma. It also suggests, as regards to the conservation, the butter of Pentadesma butyracea would grow rancid less quickly than other vegetable oils. On the nutritional plan, it represents good information because the linoleic acid is an essential fatty acid. Thus, Maritz et al. (2006) reported that the linoleic acid is an essential fatty acid that is vital in nutrition because it intervenes in the fabrication of the cell membrane and cannot be synthesized by the body. According to Maranz and Wiesman (2004), the linoleic acid content of $6-8 \%$, makes Shea oil a moderate source of essential fatty acids in the human diet. Modifications of fatty acids during cooking could be related to 2 mechanisms: oxidation, loss of fatty acids by diffusion in cooking medium. In studies on cooking beef, Ono et al. (1985) and Scheeder et al. (2001) reported a significant decrease in total saturated fatty acids and an increase in total unsaturated fatty acids as the result of cooking. The increase of unsaturated fatty acids suggests that the hydrogenation reaction is limited at warmer temperature. This observation is in agreement with the result obtained by Honfo et al. (2013) in Shea butter, who reported that higher amounts of linoleic acid were found for butter from boiled kernels.

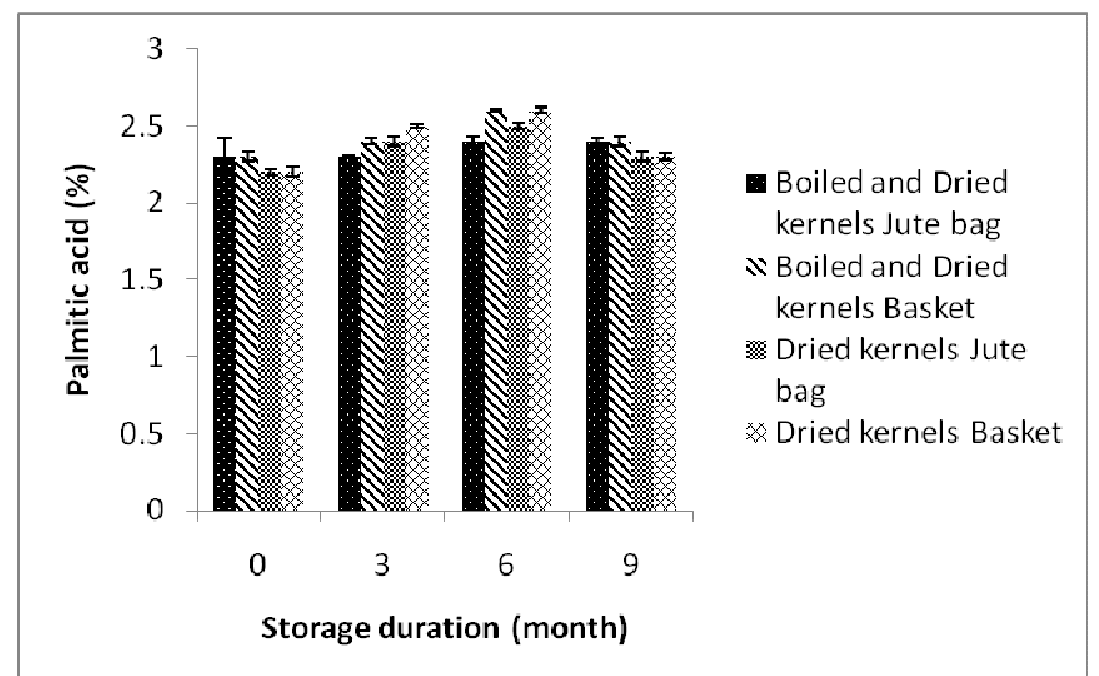

Figure 4: Effect of storage duration, pre-treatment and packaging materials on palmitic acid content of $P$. butyracea butter 


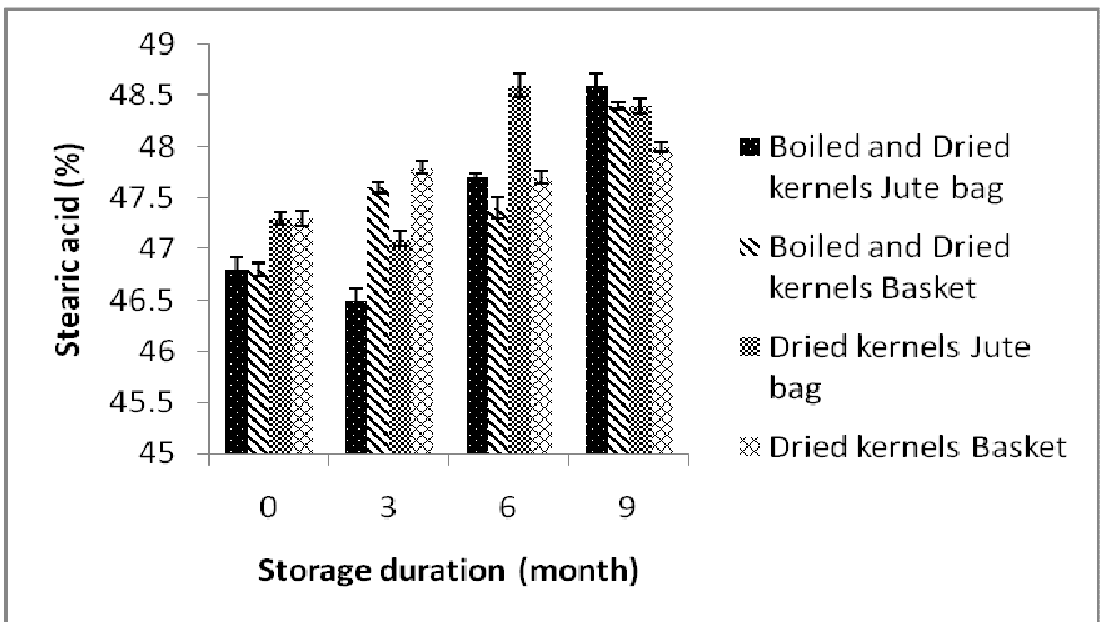

Figure 5: Effect of storage duration, pre-treatment and packaging materials on stearic acid content of $P$. butyracea butter

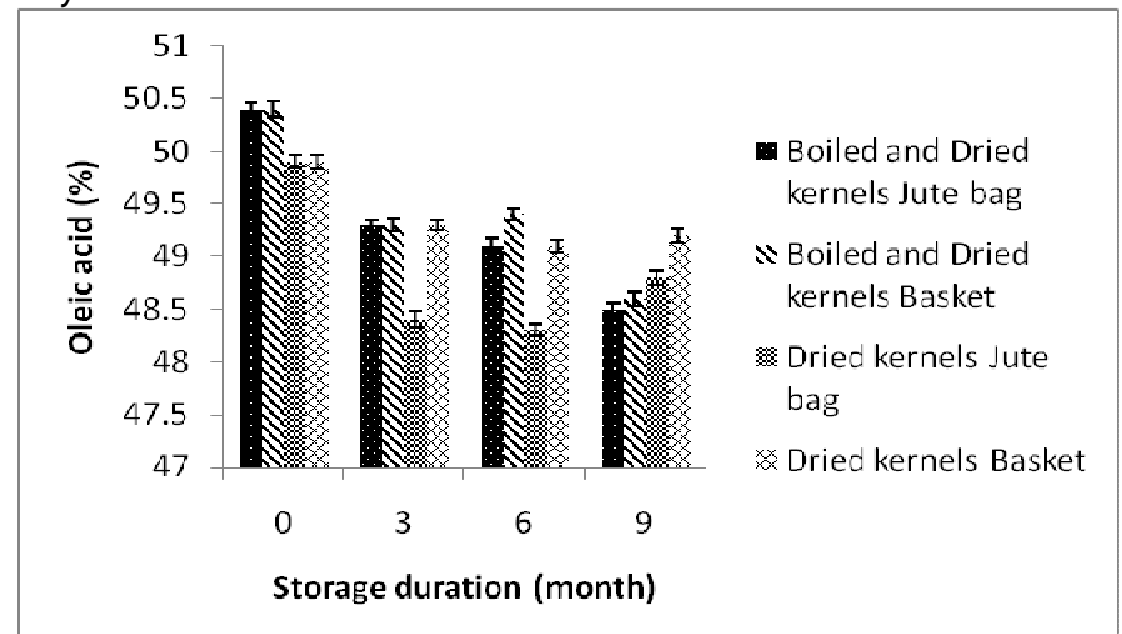

Figure 6: Effect of storage duration, pre-treatment and packaging materials on oleic acid content of $P$. butyracea butter

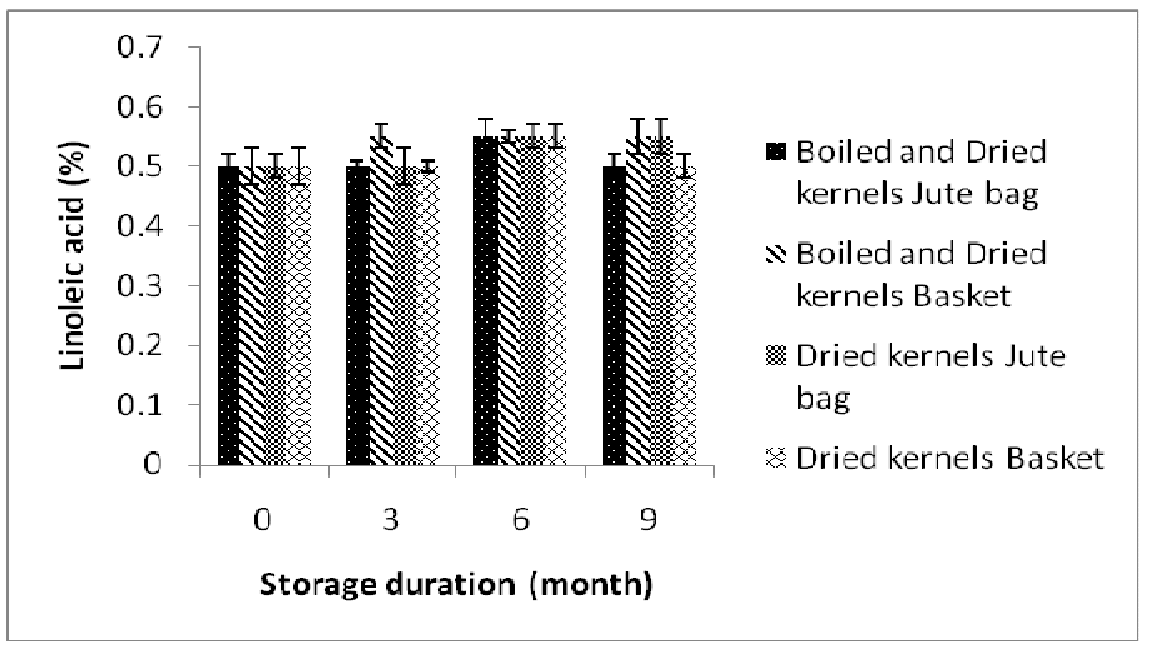


Figure 7: Effect of storage duration, pre-treatment and packaging materials on linoleic acid content of $P$. butyracea butter

\section{CONCLUSION}

The storage duration, the kernel boiling and the packaging materials significantly affected the oil yield of kernel of $P$. butyracea and the fatty acid profile of derived butter. The storage duration had a significant effect on the water content, the water activity of the kernels. Overall, the butter yield and quality were better

\section{REFERENCES}

Aïssi MV, Djoumonlo AM, Sossa HA, Soumanou MM, 2012. Evaluation de la qualité physicochimique du beurre issu des graines stockées de Pentadesma butyracea Sabine. Annales des Sciences Agronomiques $16: 10-19$.

Aïssi MV, Tchobo FP, Natta AK, Piombo G, Villeneuve P, Sohounhloué DCK, Soumanou, MM, 2011. Effet des prétraitements post-récolte des amandes de Pentadesma butyracea (Sabine) sur la technologie d'extraction en milieu réel et la qualité du beurre. Oléagineux, Corps Gras, Lipides 18 : 384-392.

Anihouvi VB, Hounhouigan JD, Ayernor SG, 2005. Production and commercialisation of "lanhouin", a fermented fish-based condiment from the Gulf of Benin. Cahiers Agriculture 14 :323-330.

AOAC, 2002. Official methods of analysis, 16 th edn. Washington, DC: Association of Official Analytical Chemists.

Avocevou-Ayisso CMA, 2011. Etude de la viabilité des populations de Pentadesma butyracea Sabine et de leur socioéconomie au Bénin. Thèse de doctorat. Université d'Abomey Calavi, Bénin. $223 p$.

Ayegnon BP, Kayodé APP, Tchobo FP, Azokpota P, Soumanou MM, Hounhouigan DJ, 2015. Profiling the quality characteristics of the butter of Pentadesma butyracea with reference to Shea butter. Journal of the Science Food and Agriculture DOI: 10.1002/jsfa.7052.

Beltrán A, Prats MS, Maestre SE, Grané N, Martín ML, 2009. Classification of Four Almond Cultivars Using Oil Degradation Parameters Based on FTIR and GC Data. Journal of American Oil Chemical Society 86: 51-58.

Dencausse L, Nsourankoua H, Artaud J, Clamou JL, 1995. Comparaison des compositions lipidiques des beurres de Pentadesma et de before six months of storage. The basket is less effective in preserving the quality of Pentadesma butyracea butter during storage. Pentadesma butyracea butter from kernels stored in jute bags maintains its physicochemical quality. The storage duration of the kernels should not exceed 6 months.

Karité. Oléagineux, Corps Gras, Lipides 2:143-147.

Evrard J, 2005. Les tourteaux d'oléagineux, source de protéines en alimentation animale. Oléagineux, Corps Gras, Lipides 12: 224-227.

Maranz S, Wiesman Z, 2004. Influence of climate on the Tocopherol content of Shea butter. Journal of Agricultural and Food Chemistry 52: 29342937.

Maritz FD, Hernadez R, Martinez G, Vidal G, Gomez M, Fernandez H, Garces R, 2006. Comparative study of Ozonized olive oil and ozonized sunflower oil. Journal of Brazil chemistry society 17: 403-407.

Natta A, Sogbégnon R, Tchobo F, 2010. Connaissances endogènes et importance de Pentadesma butyracea (Clusiaceae) pour les populations autochtones au Nord Ouest Bénin. Fruit Vegetable Cereal Science and Biotechnology 4:18-25.

Nkouam GB, Barth D, Dirand M, Tchatcheng JB, 2007. Oil extraction from Shea kernel (Vitellaria paradoxa, Gaertn.) and Canarium pulp (Canarium schweinfurthii, Engh) using supercritical $\mathrm{CO} 2$ and hexane: a comparative study. Research Journal of applied Science 2: 646-652.

Nuernberg K, Kuechenmeister $U$, Nuernberg G, Hartung M, Dannenberger D, Ender K, 2006. Effect of storage and grilling on fatty acids in muscle of pigs fed plant oils. European Journal of Lipids Science Technology 108:554-560.

Ono K, Berry BW, Parozczay E, 1985. Contents and retention of nutrients in extra lean, lean and regular ground beef. Journal of Food Science 50:701-706.

Scheeder MRL, Casutt MM, Roulin M, Escher F, Dufey PA, Kreuzer M, 2001. Fatty acid composition, cooking loss and texture of beef patties from 
meat of bulls fed different fats Meat Science 58: 321-328.

Sinsin B, Sinadouwirou TA, 2003. Valorisation socioéconomique et pérennité du Pendesma butyracea Sabine en galeries forestières au Bénin. Cahiers Agriculture 12:75-79.

Tchobo PF, Natta AK, Barea B, Barouh N, Piombo G, Pina $M$, Villeneuve $P$, Soumanou MM, Sohounhloue CKD, 2007. Characterization of Pentadesma butyracea Sabine butters of different production regions in Benin. Journal of American Oil Chemical Society 84: 755-760.

Tchobo PF, Alitonou GA, Noudogbessi JP, Laguerre M, Barea B, Piombo G, Natta AK, Villeneuve P, Soumanou MM, Souhounhloue DCK, 2013. Evaluation of the chemical composition of Pentadesma butyracea butter and defatted kernels. International Journal of Biosciences 3:101-108.

Vantomme P, 1999. FAO. Activités relatives aux produits forestiers non ligneux. OIBT, Actualités des Forêts Tropicales 7: 25-33.

Welti-Chanes J, Perez E, Guerrero-Beltran JA, Alzamora SM, Vergara-Balderas E, 2007. Applications of water activity management in food industry. In water activity in foods: fundamentals and applications, ed. GV Barbosa-Canovas, AJ Fontana Jr, SJ Schmidts TP Labuza pp. 341-358. 